\title{
Attitudes Toward Technology Among Distance Education Students: Validation of an Explanatory Model
}

\author{
Sonia J. Romero Martínez \\ Faculty of Health Sciences and Education, Madrid Open University, Madrid, Spain \\ Xavier G. Ordóñez Camacho \\ Department of Psychology and Research in Education, Complutense University of Madrid, \\ Madrid, Spain \\ Francisco D. Guillén-Gamez* \\ Department of Education, University of Almeria, Almeria, Spain \\ Javier Bravo Agapito \\ Faculty of Technical Sciences and Engineering, Madrid Open University, Madrid, Spain
}

\begin{abstract}
:
Attitudes toward technology are preconceived notions that affect the teaching-learning process and the academic-professional performance of students, in particular those who use technology. This investigation has two objectives: to test the measuring properties (reliability, factorial structure) of an instrument that measures attitudes and to propose and validate a model that hypothesizes digital competence and frequency of use of technologies have a positive impact on attitudes. The sample included 1,251 students of the Madrid Open University in a nonexperimental, explanatory study using structural equation methodology. The results indicated adequate psychometric properties for the test and good adjustment of the proposed model $\left(\chi^{2}=163.91, \mathrm{df}=37, p<.001\right)$ allowing for further exploration of the relationship between use, skill, and attitudes in the distance education context and improving the properties of measuring instruments proposed in Spanish.
\end{abstract}

Keywords: attitudes toward technologies, distance education, structural equation models, digital competence, use of technology

Romero Martínez, S.J., Ordóñez Camacho, X.G., Guillén-Gamez, F.D., \& Bravo Agapito, J. (2020). Attitudes toward technology among distance education students: Validation of an explanatory model. Online Learning, 24(2), 59-75. https://doi.org/10.24059/olj.v24i2.2028

*Corresponding author: Francisco D. Guillén-Gamez. Address: Edificio Departamental de Humanidades y Ciencias de la Educación I (Edif. A) Planta 2, Despacho 38, Universidad de Almería, Carretera Sacramento s/n, 0420 La Cañada de San Urbano. Almería. Phone:+34 950015258 email: dguillen@ual.es 


\section{Attitudes Toward Technology Among Distance Education Students: Validation of an Explanatory Model}

In all spheres of life, including education, people are living a life of constant immersion in Information and Communication Technology (ICT). This has led to major changes in the field of education over recent decades, especially distance education where the context makes the use of ICT a necessity. ICT tools have transformed the teaching-learning process in many ways (Alhom \& Courtney, 2018; Abdelmalak, 2015; Rodríguez, Restrepo \& Aránzazu, 2014): increasing higher order thinking skills, problem solving skills, and the effectiveness of teaching and learning. Technologies in education include different environments designed specifically to fulfill certain objectives in teaching and learning. The most commonly used ICT resources include the Internet, multiplatform applications, communication tools such as mobile messaging, email and social media, and tools for sharing files and other resources like blogs, e-portfolio, MOOCs, web conference applications, etc.

Additionally, Learning Management Systems (LMSs) like Moodle, Sakai, LAMS, and Blackboard Learn Collaborate offer today's students different opportunities for online learning. Rhode, Richter, Gowen, Miller, and Wills (2017) point out that LMSs make the education process independent of students' time and location. Moodle, in particular, allows for the creation of effective online courses, using study material in the form of text files, images, presentations, audio and video files, working with glossaries, wikis, databases and interactive communication with students through forums, among others (Kerimbayev, Kultan, Abdykarimova \& Akramova, 2017).

Abdelmalak (2015) established that the use of 2.0 tools in the teaching-learning process is indispensable, especially in distance education. This has led to increased interest in the study of personal and academic variables that might lead a user to have greater or lesser digital competency (He \& Zhu, 2017; Ahmed, 2017). Among the most researched variables are the motivation of students toward ICT (Logan, Lundberg, Roth \& Walsh, 2017; Senkbeil \& Ihme, 2017), the possible gender differences on competency and frequency of use (Laabidi, 2017), and the effect of positive attitudes in the increase of shared information sharing knowledge (Podrug, Filipović \& Kovač, 2017; Nisar \& Haque, 2018). However, the use of these platforms and the resources available for achieving significant learning is conditioned by the attitudes of students toward the technology. This is why the objectives of this work are twofold: on the one hand, to check the properties (reliability, factorial structure) of an instrument to measure the attitudes among distance university students toward ICT and, on the other hand, to propose and validate a model that hypothesizes digital competency and the frequency of use of technologies has a positive impact on these attitudes.

In a general sense, attitudes can be defined as the positive or negative sensation regarding a specific issue (Binder \& Nierdele, 2006). Attitudes are predispositions that are learned and change throughout people's live. Some authors consider them not to be innate, that they can be changed to achieve more appropriate attitudes (Binder \& Niederle, 2006). For Ayub (2017), attitudes are opinions a person has of things, people, or some issue. The general attitude toward an issue may be positive, negative, neutral or may vary from one situation to another. In particular, the attitudes toward the inclusion of ICT in teaching can be defined as the ideas, preconcepts, beliefs, and opinions of students on the incorporation of ICT in the teaching-learning process and depend on the previous experience with technology (Binder \& Nierdele, 2006). In most studies on attitudes, three components come into play: cognitive, affective, and behavioral, with the affective 
taking greatest weight, followed by cognitive and behavioral with the lowest weight (Mirete, García \& Hernández, 2015).

For Adekunle, Omoba, and Tella (2007), one of the most important personal variables for the epistemological development of students are their attitudes. Several authors have found that use of ICT is conditioned by the attitude of students as well as their knowledge of ICT (Tejedor, García-Valcárcel, \& Prada, 2009). Yang and Kwok (2017) and Meerza and Beauchamp (2017) have found that a positive attitude toward ICT is a necessary condition for the use of ICT in teaching students to be effective learners online. These results have led to increased interest in the study of variables that might impact attitudes toward the use of ICT. The variables analyzed include self-perceived digital competence, frequency of use of the technologies, and the perception of the utility of same.

\section{Review of Relevant Literature}

Over the last decade, several studies investigated the effects of different variables on the attitudes of students at different levels of education and their relationship with the teachinglearning processes in different contexts.

Nketiah-Amponsah, Asamoah, Allassani, and Aziale (2017) examined students' attitudes on the use of some selected ICT devices and applications and their academic performance. A sample of 320 final year undergraduate students of the University of Professional Studies Accra, Africa (UPSA) produced a positive and statistically significant relationship between attitude toward the use of some 2.0 tools and academic performance. Specifically, a positive attitude toward the use of email has a positive impact on academic performance, while a positive attitude toward the use of the iPad had a negative impact. In contrast to these results, Petko, Cantieni, and Prasse (2017) analyzed the relationship between attitudes toward ICT using data collected from the Programme for International Student Assessment (PISA 2012) report on Mathematics, Science, and Reading, which included the academic performance of around 510,000 15-year-old students from 65 countries. No positive associations between attitudes toward the use of ICT and the school performance of students were found. It is likely that positive attitudes toward ICT are the result of positive experiences; therefore, it seems reasonable to conclude that what really matters is the quality rather than quantity of use of educational technology. Along the same lines, Stošić and Fadiya (2017) examined attitudes of students toward the use of ICT during their studies using a sample of 285 students from Girne American University (Turkey). Attitudes to ICT had a significant impact on the academic performance of the student because students with higher scores in attitude get better mean grades. Mantoro, Fitri, and Usino (2017) investigated the impact of ICT on the learning process and student attitudes using a sample of 20 students at a vocational school in Tangerang (Indonesia). The use of ICT created a fruitful learning process and fostered positive attitudes in students. Siragusa and Dixon (2008) studied attitudes from a small group of undergraduate students $(n=30)$ in a higher education institution in Australia on their use and engagement of ICT. The study found that negative attitudes can cause students to feel anxious or intimidated when they use technologies.

Another group of investigations have focused on the variables that might influence the development of favorable attitudes toward technology. Kubiatko (2010) studied differences in attitudes toward ICT according to sex, age, year of study, and type of residence in a sample of 316

Czech students. In general, the students reflected positive attitudes toward ICT, even though men, 
second-year students, and students living in rural areas showed a more positive attitude in comparison to women and urban students. Casillas, Cabezas, Ibarra, and Rodríguez (2017) evaluated the digital competence of 580 education students at the University of Salamanca (Spain). Digital competence was measured through three dimensions: knowledge, use of, and attitudes toward ICT. Results found a more favorable attitude in female students than in male students even though males showed higher levels of knowledge and use of technology. In contrast, Rhema and Miliszewska (2014) evaluated the attitudes of 348 engineering students at the University of Tripoli (Libya) regarding their demographic characteristics, access to technology, use of technology for learning, skill in technology, and satisfaction with technology. no differences were found on these measures by gender or habitat (rural-urban) of the students with respect to their attitude toward ICT. Similarly, Kar, Saha and Mondal (2014) measured the attitude of 308 university students toward e-learning and found no differences with respect to gender, place of birth, or study discipline in relation to ICT.

García, Escofet, and Gros (2009) compared attitudes to ICT of 1,042 students enrolled in five Catalan universities (Spain) with different models, virtual, and blended. They analyzed whether different variables affected students in their level of attitude toward ICT (age, gender, university institution of origin, model: virtual or face-to-face, and area of knowledge). Attitudes toward ICT were measured on three dimensions: cognitive, social, and teaching. Significant differences were found between distance education and face-to-face students in the components of attitude except for the efficient development of knowledge and skills.

\section{The Proposed Model}

The model proposed in this study hypothesizes that technology use and self-perceived digital competence influence attitudes toward technology. The model is based on prior studies of the effect on attitudes of variables like Digital Competence (DC) or technology use. DC can be defined as a competence that allows the student to develop autonomously in a globalized society connected through technology and where information is increasingly growing. Nevertheless, said competence not only refers to possessing the knowledge and command of 2.0 tools but also putting them into practice (Cervera, Vidal, \& Martínez, 2011).

DC can also be defined as the safe and critical use of ICT for work, leisure, and communication. In addition, a person will possess a correct DC when he / she is able to collect information, reflect and create knowledge, as well as communicate and share it through collaborative networks. (Aesaert, Van Nijlen, Vanderlinde \& Van Braak, 2014). For Gallego, Gámiz, and Gutiérrez (2010), DC is formed by cognitive knowledge, attitudes, and procedural skill in the use of ICT. Rhema and Miliszewska (2014) have found that the self-perceived level of DC significantly influences attitudes toward educational technology.

Aesaert, Voogt, Kuiper, and Van Braak (2017) tried to identify the characteristics related to a student's self-perceived DC. The sample was composed of 378 sixth-grade students from 58 primary schools in Flanders (Belgium). Students' self-perceived DC were compared with an ICT competence test based on performance. The results indicate that current ICT ability and prior experiences are related positively with the self-perceived DC.

The second independent variable in our model is use of ICT. Gallardo, Marqués, and Bullen (2015) stated the way in which students interact with technological devices and 2.0 tools has 
changed substantially. The current generations born after the 1980s have therefore lived with digital technology from birth (digital tablets, laptops, computers, etc.).

Fancovicová and Prokop (2008) analyzed if attitudes are influenced by the use of technology and other variables like accessibility to technology, personal characteristics, and educational context using a sample of 214 secondary students from four different Slovak elementary schools. The instrument was constructed of three dimensions: cognitive, behavioral. and affective. $\mathrm{T}$ attitudes toward the use of ICTs between different educational contexts (for example, online versus face-to-face) were different. The time spent on computers was positively correlated only with the behavioral dimension.

Mehra and Omidian (2011) also studied the relationship between attitudes toward technology, technology use, and perceived DC among 400 postgraduate students from the University of Punjab from different departments. They created an instrument with 48 items, whose results showed a positive attitude among the students who also considered ICT to be useful. However, only a little over half of the sample was in favor of adopting ICT in learning processes.

\section{Explanatory Models of Attitudes toward ICT}

Liaw, Huang, and Chen (2007) studied the attitudes toward ICT in 50 professors and 168 college students of distance education courses. The authors proposed a three-level model called Three-Tier Technology Use Model (3-TUM) derived from TAM (Technology Acceptance Model): the first level consists of the individual's experience regarding the quality of the LMS and the ICT tools, the second level includes the student's attitude in its cognitive and affective components, and the third level is comprised of the behavioral intention to use the ICT. Testing of the model showed that the attitude of students is influenced by the instructional pace, as managed by the teacher with the support of multimedia tools. However, this study is exploratory and a causalexplanatory analysis is required.

Edmunds, Thorpe, and Conole (2012) proposed the Technology Acceptance Model (TAM) to analyze attitudes toward ICT in three different contexts: work, leisure, and course study using a sample of 421 university students. The model suggested a causal influence of perceived digital competence and utility on attitudes and acceptance toward ICT. The comparison between contexts indicated that the students described utility in work significantly higher than other areas (leisure or study). The comparison by the study discipline indicates that technology students obtained significantly higher grades than those in other disciplines.

In the present study tests the TAM model on distance education students, just as the work of Edmunds, Thorpe, and Conole (2012) was carried out on face-to-face format students. For the model tested here the 3-TUM model was used. This model also was taken as background because even though these authors worked with distance education students in their research, it is exploratory rather than explanatory. For this reason, the present study formulated the following hypothesis: self-perceived digital competence and the frequency of use of ICT have a positive effect on attitudes to ICT among distance education university students. The causal model proposed in the present study is presented in Figure 1. 


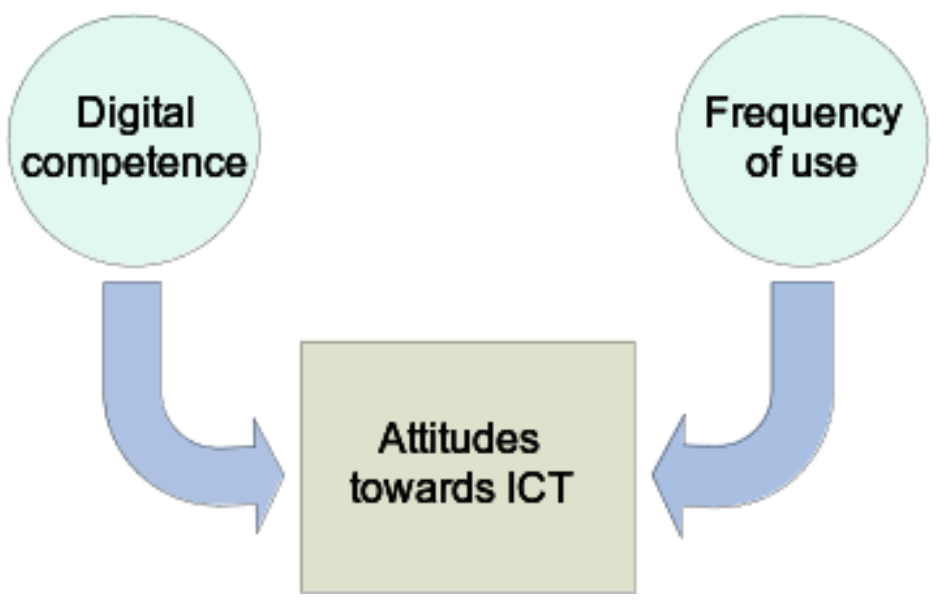

Figure 1. Causal model proposed in the present study

\section{Methods}

\section{Data collection}

A total of 1231 students from the Distance University of Madrid (UDIMA) participated in the study on a voluntary basis and with informed consent. The instruments were sent by email to all UDIMA students registered during the 2015-2016 course both in bachelor's and master's courses (the population of students in UDIMA is $N=5776$ ). The email included an explanation of the objectives of the study and their consent to participate. The rate of response was $21.3 \%$, which is somewhat low because they did not have any incentive to respond, either economic or academic. The sample included 601 women and 630 men. Some of the sample $(62.47 \%)$ were bachelor's students and distributed as follows: 147 students of Engineering, 100 Law, 99 Criminology, 94 Education, 78 Psychology, 72 Labour Sciences, 66 Journalism, 62 Company Administration, 23 History, 10 Humanities, 9 Economics, and 9 Tourism. Their age ranges from 18 to $69(M=36.01$, $\mathrm{SD}=9.59$ ). An important characteristic of the sample is that $40 \%$ of the students are employed in areas related to ICT and more than 50 have previous degree studies. The investigation was carried out in accordance with the ethical consideration established in the Declaration of Helsinki (World Medical Association, 2001).

\section{Instruments}

The instrument used includes three types of test: one to measure attitudes toward ICT, other to measure digital competence and one to measure frequency of use of ICT tools. The first one (attitudes) has been designed specifically for this investigation. The test is comprised of 20 items distributed on three scales: cognitive ( 7 items), affective ( 8 items), and behavioral (5 times). Each item contains a statement on thoughts, beliefs and attitudes to the incorporation of ICT in the learning process. The test used a Likert type format with 5 response options from 1 (completely disagree) to 5 (completely agree). The test is presented in Table 2 of the Results section.

The second instrument (self-perceived digital competence) appears in Appendix A. The questionnaire is composed of 15 questions in which each student evaluates their own capacity on a scale of 1 to 4 to develop actions with digital devices (computers, tablets, and smartphones). The actions selected were a subset of the actions included in a previous questionnaire by Carrera, 
Vaquero, and Balsells (2011). The subset of actions includes action with digital devices; other actions as multiplatform applications were removed to abbreviate testing length.

Finally, students were asked about their frequency of use of a list of 24 technology resources commonly used at UDIMA divided into five groups: digital devices, Moodle, communication tools, collaboration tools, and other tools. The frequency of use was measured on a Likert scale from 1 ("I don't use it) to 4 (I use it very frequently). This instrument was also designed for this study and is presented in Appendix A.

\section{Reliability}

First, after the questionnaire on attitudes was prepared, five specialists in Education and ICT (lecturers in the master's in Education and Technology program) assessed the content and the syntactic and semantic adequacy of each item. They also evaluated the congruence of each item with respect to the factor it measured, and for this purpose were informed of the definition of the three factors that comprise the instrument (affective, cognitive, and behavioral). They were asked to pair each item with one of said factors. The percentage of items paired correctly ranged from $45.8 \%$ to $83 \%$ : evaluator $1(11 / 24=45.8 \%)$; evaluator $2(15 / 24=62.5 \%)$; evaluator $3(20 / 24=$ $83 \%)$; evaluator $4(12 / 24=50 \%)$; and evaluator $5(17 / 24=70.8 \%)$ indicting partial evidence of validity of the content. The other evaluations indicate easy comprehension of the items.

After obtaining the final version of the instrument, a subsample of 85 students with similar characteristics to the target population responded with the objective of obtaining data for the psychometric analysis. The reliability obtained in said pilot test was: $\alpha=0.93$ (digital competence), $\alpha=0.83$ (frequency of use), and $\alpha=0.77$ (attitude). At the end of the pilot test, the following questions on the quality of the instrument were included:

(a) Are the questions clear?

(b) Is there any ambiguity in the questions?

(c) Is there any important aspect that is not considered?

(d) Do the questions correspond to the objectives of each test component?

(e) Is there any additional question that might improve this instrument?

The responses to these questions allowed for the inclusion in the digital competence instrument of several digital tools not considered in the original draft (e.g., glossaries, wikis, and calendars) and also the removal of others students did not use at all such as QR codes. All members of the pilot sample considered the questions to be clear.

\section{Data analysis}

This study can be defined as nonexperimental, explanatory, transversal, recursive, and onedirectional. The data analysis included several procedures, all of which are derived from the structural equation model detailed next.

Confirmatory factor analysis (CFA) has been used as a tool to compile evidence of factorial validity of the attitude test. Due to polytomous nature of the items, the Generalized Least Squares (GLS) method was used as an entry to the asymptotic covariance matrix analysis. To analyze the adjustment of the model, various indices have been considered, as recommended by Brown and Moore (2014): Satorra-Bentler's $\chi^{2}$ and the level of statistical meaning, the Root Mean Square Error of Approximation (RMSEA) with its respective confidence interval of $90 \%$, the Comparative 
Fit Index (CFI), the Non-Normed Fit Index (NNFI), and the Standardized Root Mean Square Residual (SRMR). The values must be below 0.06 for RMSEA and SRMR and above 0.95 for CFI and NNFI indices. The CFA results also provided composite reliability, factorial saturation, average variance extracted, and convergent and discriminant validity.

Reliability was studied through internal consistency (Cronbach's $\alpha$ ) for each of the scales and for the total test, with its respective confidence interval.

To test the explanatory model proposed in Figure 1, modelling using structural equations was used. GLS was used as a method of analysis. To evaluate the adjustment of the model, the criteria presented previously for the CFA were analyzed.

The statistical packages SPSS v.20, LISREL 8.80 and Prelis 2.80 (Jöreskog \& Sörbom, 2006) were used to carry out the analyses.

\section{Results}

\section{Psychometric properties of the questionnaire on attitudes to ICT}

Table 1 shows the indices of the adjustment of CFA and reliability according to internal consistency. Table 2 presents the composite reliability, the AVE (Average Variance Extracted of each factor), and the factorial loads of each of the items obtained through CFA.

Table 1

Indices of Adjustment of CFA and Reliability

\begin{tabular}{|c|c|c|c|c|c|c|c|}
\hline$\chi^{2} \mathrm{SB}$ & $G l$ & $p$ & CFI & NNFI & SRMR & RMSEA & $90 \% \mathrm{CI}$ \\
\hline 693.83 & 166 & $<.001$ & .97 & .97 & .041 & .054 & [.050-.059] \\
\hline \multicolumn{3}{|c|}{ Reliability } & \multicolumn{2}{|r|}{ Affective } & Cognitive & Behavioral & Total \\
\hline \multicolumn{3}{|c|}{ Cronbach's Alpha } & \multicolumn{2}{|r|}{.735} & .801 & .767 & .903 \\
\hline
\end{tabular}

As can be seen in Table 1, the reliability through internal consistency is adequate. The AVE (see Table 2) indicates that the Affective factor explains $86 \%$ of the variance, the Behavioral $78 \%$, and the Cognitive $87 \%$. These values exceed the recommended 50\%, indicating good measurement of the construct (Hair, Black, Babin, \& Anderson, 2010). With respect to the composite reliability, the values are higher than those obtained through internal consistency. With respect to the convergent validity, the 20 test items have statistically significant factorial loads ( $T$ values above 1.96) representing the factor they saturate. 
Table 2

Saturations, Composite Reliability and Factorial Loads in CFA

\begin{tabular}{|c|c|c|c|c|}
\hline Factor & FC & AVE & Item & $\lambda$ \\
\hline \multirow[t]{8}{*}{ Affective } & 0.86 & 0.59 & $\begin{array}{l}\text { I would like to have more technological resources for } \\
\text { my studies. }\end{array}$ & $0.48^{*}$ \\
\hline & & & I feel at ease using ICT for my university studies. & $0.99 * *$ \\
\hline & & & $\begin{array}{l}\text { I get overwhelmed accessing so much information on } \\
\text { the internet. }\end{array}$ & $0.66^{*}$ \\
\hline & & & $\begin{array}{l}\text { When choosing my University, I took into account } \\
\text { whether ICT would be used in teaching. }\end{array}$ & $0.64 *$ \\
\hline & & & I like to work in virtual classes. & $0.75^{* *}$ \\
\hline & & & ICT have changed my way of learning. & $0.84 * *$ \\
\hline & & & I like to study through ICT. & $0.94 * *$ \\
\hline & & & $\begin{array}{l}\text { I worry that in my professional future I will have to use } \\
\text { ICT more. }\end{array}$ & $0.71 * *$ \\
\hline \multirow[t]{5}{*}{ Behavioral } & 0.78 & 0.81 & ICT facilitates my study of the subjects. & $0.97 * *$ \\
\hline & & & $\begin{array}{l}\text { I would like to have more technological resources for } \\
\text { my studies }\end{array}$ & $0.73 * *$ \\
\hline & & & I feel at ease using ICT in my university studies. & $0.96 * *$ \\
\hline & & & $\begin{array}{l}\text { I get overwhelmed accessing so much information on } \\
\text { the Internet. }\end{array}$ & $0.90 * *$ \\
\hline & & & My way of studying is helped by use of ICT. & $0.93 * *$ \\
\hline \multirow[t]{7}{*}{ Cognitive } & 0.87 & 0.81 & ICT assists me in my learning. & $0.96 * *$ \\
\hline & & & ICT is important at this current moment in my training. & $0.98 * *$ \\
\hline & & & $\begin{array}{l}\text { I believe the integration of ICT into my study process to } \\
\text { be a positive thing. }\end{array}$ & $0.98 * *$ \\
\hline & & & ICT is irrelevant in my learning. & $0.77 * *$ \\
\hline & & & ICT allows me to acquire basic skills for my career. & $0.93 * *$ \\
\hline & & & $\begin{array}{l}\text { ICT provides flexibility of space and time to } \\
\text { communicate with teachers and fellow students. }\end{array}$ & $0.81 * *$ \\
\hline & & & $\begin{array}{l}\text { Use of ICT hinders the development of my professional } \\
\text { skills. }\end{array}$ & $0.84^{* *}$ \\
\hline
\end{tabular}

Note. $\mathrm{CR}=$ Composite Reliability; $\mathrm{AVE}=$ Average Variance Extracted; $\lambda=$ Factorial Loads

* Significant load $p<.05 ; * *$ Significant load $p<.01$ 
Table 3 presents evidence of the discriminant validity. The AVE is above the square of the correlation between the factors in the case of the affective-behavioral and affective-cognitive factors, evidencing the discriminant validity between these factors. The same does not occur between the factors in the case of the behavioral and cognitive factors as AVE is below that of the square of their correlation.

Table 3

Evidence of Discriminant Validity

\begin{tabular}{llll}
\hline & Affective & Behavioral & Cognitive \\
\hline Affective & .86 & & \\
Behavioral & .31 & .78 & \\
Cognitive & .29 & .90 & .87 \\
\hline
\end{tabular}

Note. Average Variance Extracted on the diagonal.

\section{Explanatory model of Attitudes to ICT based on frequency of use and self-perceived digital competence}

Table 4 shows the indices of adjustment of the structural equations model proposed in this study. It also includes the total reliability of each of the instruments used.

Table 4

Fit of SEM Model and Reliability of the Instruments

\begin{tabular}{|c|c|c|c|c|c|c|c|}
\hline$\chi^{2}$ & $D f$ & $p$ & CFI & NNFI & SRMR & RMSEA & $90 \% \mathrm{CI}$ \\
\hline 163.91 & 37 & $<.001$ & .99 & .98 & .041 & .052 & {$[.044-.061]$} \\
\hline Test & & & & DC & FUSE & QAITC & Total \\
\hline Reliabil & (Cro & bach's & & .94 & .88 & .90 & .88 \\
\hline
\end{tabular}

Note. $\overline{\mathrm{DC}}=$ Digital Competence; FUSE $=$ Frequency of Use; QAITC $=$ Questionnaire on Attitudes to ICT.

The model's adjustment is very good because it meets the criteria specified in the data analysis section. Therefore, it is possible to proceed with the analysis of the different components of the model. Figure 2 shows the factorial loads $(\lambda)$ of the measurement model and the estimated parameters $(\gamma)$ for the structural model (causal). 


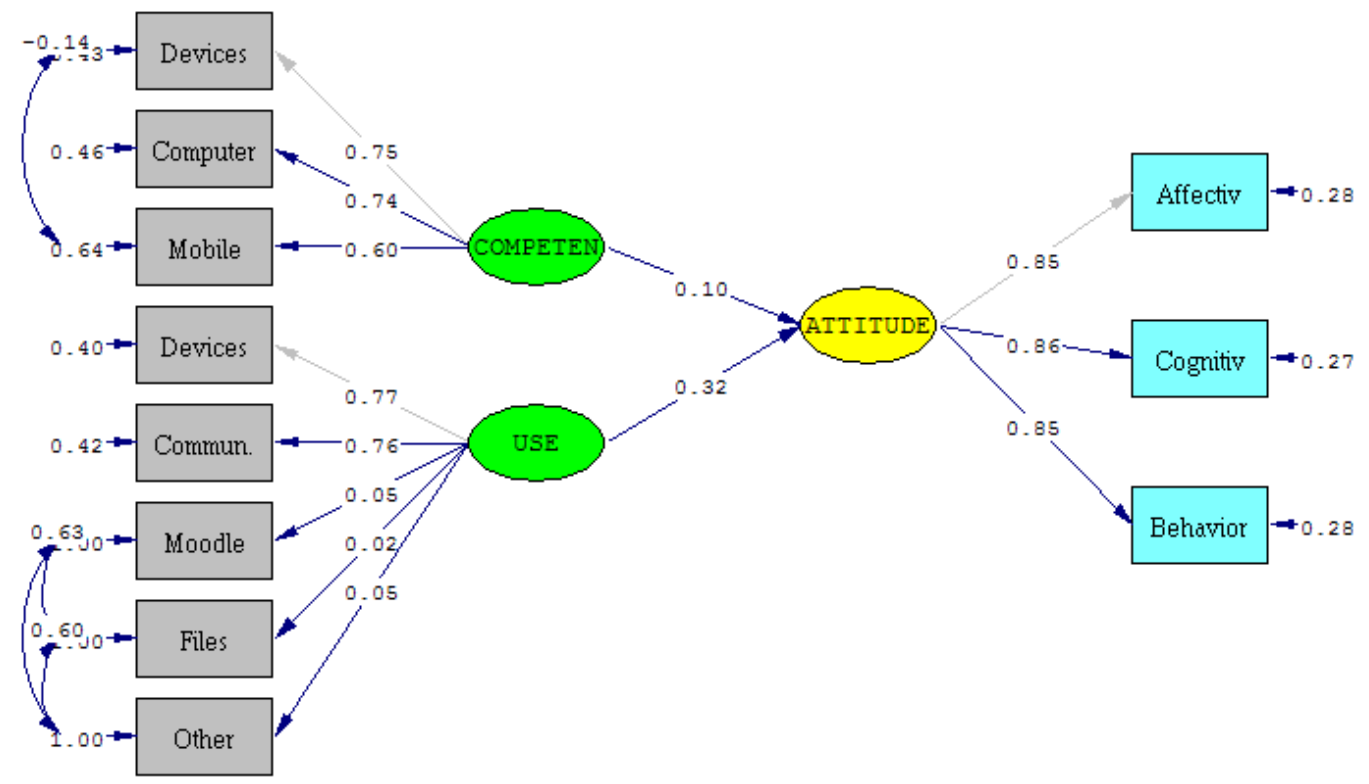

Figure 2. SEM model

Regarding to the measurement model, all $\lambda_{\mathrm{y}}$ parameters $(.85, .86$, and .85$)$ were positive and statistically significant (student's $T=50,55$, and 55.36, respectively). The same occurs with the parameters $\lambda_{\mathrm{x} 1}$ (self-perceived digital competence); all the parameters were positive and statistically significant: $\lambda_{11}=0.75, t=34.6 ; \lambda_{21}=0.74, t=27.51$; and $\lambda_{31}=0.60, t=21.7$.

With respect to frequency of use of ICT tools, some of the $\lambda_{\mathrm{x} 2}$ parameters were not significant: the frequency of use of Moodle $\left(\lambda_{32}=0.05, t=1.57\right)$, file-sharing tools $\left(\lambda_{42}=0.02, t=\right.$ $0.79)$, and other tools $\left(\lambda_{52}=0.05, t=1.78\right)$, that indicates that frequency of use is defined primarily as use of devices $\left(\lambda_{12}=0.76, t=38\right)$ and by communication tools $\left(\lambda_{22}=0.75, t=31\right)$.

With regards to the structural model, the parameters that relate self-perceived digital competence with attitude were not significant $\left(\gamma_{11}=.10, \mathrm{t}=.86\right)$ but the parameter that related frequency of use with attitude was $\left(\gamma_{12}=.32, \mathrm{t}=2.61\right)$. This indicates that high use of technologies produces more positive and developed attitudes toward ICT; however, digital self-perceived digital competence has no impact on these attitudes.

\section{Discussion}

At present, attitudes toward ICT represent a valuable field of study for education. Its importance is reflected in the variety of studies and investigations that have been carried out on the topic. A couple of models have been proposed that relate attitudes with the use of technology or the digital competence like the 3TUM (Liaw, Huang, \& Chen, 2007) or the TAM (Edmunds, Thorpe, \& Conole, 2012). Also, some theoretical models explain attitudes such as Shared Planning Theory (Siragusa \& Dixon, 2008). However, these models are not causal and therefore do not 
consider the influence of different variables on attitude or how they relate to different constructs. It is important to highlight that the model presented in this study includes the influence of selfperceived DC and frequency of use of ICT on the attitude variable. Besides, these results indicated that self-perceived DC does not influence the attitude variable in contrast that Kubiatko (2010), Mehra and Omidian (2011), and Aesaert et al. (2017) obtained. It is important to note that the sample used in this work is composed completely by distance learning students. This result is different than results of previous works because distance learners could be different than face-toface learners (García, Escofet, \& Gros, 2009). Moreover, these results are similar, but more reliable than Mantoro, Fitri, and Usino (2017), since the sample used in this study was larger, perhaps resulting in the result that frequency of use of ICT has a positive effect on attitudes to ICT.

There is little consensus on the instruments used in the different investigations. Researchers usually use questionnaires to collect data, generally carried out independently for each investigation and not all verify the instruments of the measurement properties. This study, however, proposed an explanatory model but also analyzed the psychometric properties of the measurement instrument. It has been verified that the factorial loads are statistically significant and that the instrument presents convergent and discriminant validity. Through AVE, it has also been confirmed that the three factors explain over $70 \%$ of variance of the items and through internal consistency and composite reliability, it has been verified that the test is reliable.

The validation of the proposed model allowed an explanation of the attitudes and to obtain greater knowledge of said construct. This knowledge might lead others to focus on the variables that can have an impact on these attitudes through programs that foster those attitudes.

The conclusions of this study are: (a) evidence of the validity and reliability of the test for measuring attitudes has been presented; (b) a large and representative sample of the different degrees of the UDIMA have been used; (c) the causal influence of frequency of use of digital devices and computers on attitudes to ICT has been confirmed, and (d) the influence of student's self-perceived digital competence on attitude was rejected. These conclusions could allow teachers to generate programs to increase the use of various tools, such as digital devices, and thus reinforce the positive attitudes of students. This reinforcement also has an effect on improving the teachinglearning process as students acquire more significant learning.

Another important contribution of this study is to provide the scientific community with a reliable and valid tool to measure the attitudes toward incorporating ICT into the education. Its application is simple and brief (only 20 items) that Mehra and Omidian (2011) work. It also allows for the attitudes of students in the affective, cognitive, and behavioral factors to be precisely identified. Identifying students with low digital competence or negative attitudes allows for actions to be taken geared toward improving attitudes and competence of certain groups of students who need it most. It might also be helpful for teachers who can measure initial attitudes and skills and see how they change after intervention or a period of education.

This investigation also has a limitation that might constitute future lines of research. One of these is that the model establishes causal relationships between two independent and one dependent variable. However, other variables that might be important were not considered so as to simplify the model. Future studies might include other variables such as the use of technology or the average digital competence on an objective basis (not self-perceived). Another limitation is that this study used a sample of students with greater familiarity with technology in general and with Moodle in particular. In addition, $40 \%$ of participating students are employed in areas related 
to ICT and more than $50 \%$ have previous degree studies, making them students with a very particular profile. These characteristics make it difficult to generalize the results to other educational contexts despite the broad size of the sample. Subsequent studies might replicate the model in other educational contexts such as blended or face-to-face learning.

Another possible direction for future research is analysis of the attitudes of teachers as fundamental stakeholders in the educational process. Finally, other future studies might center on the comparison between private and public universities, men and women, degrees and levels of study, among others.

\section{Author Information}

Sonia J. Romero is a PhD in Psychology from the Universidad Autónoma de Madrid, Master in Methodology of Behavioral Sciences at the Universidad Autónoma de Madrid, Specialist in Statistics from the Universidad Nacional de Colombia. Currently she is Tenured Professor and Senior Researcher in the Faculty of Health Sciences and Education at the Madrid Open University. She teaches Data Analysis, Research Methodology, Psychometrics and Statistics. Her main areas of research are analytics applied to distance education, structural equation modelling, and cognitive diagnosis models.

Xavier G. Ordóñez is a Ph.D. Associate Professor at the Universidad Complutense de Madrid. $\mathrm{He}$ is a Master in Methodology of Behavioral Sciences at the Universidad Autónoma de Madrid and a Ph.D. in Education from the Universidad Complutense de Madrid. He currently teaches undergraduate and post-graduate courses in Statistics, Quantitative Methods of Research and Assessment in Education. His areas of research are measurement in education, psychometrics and instrument development with a special interest in online education measurement.

Francisco D. Guillén Gámez is Primary Education Teacher by the University of Málaga (UMA), Master's Degree in Statistical Research by the Complutense University of Madrid (UCM), Master of Education and New Technologies and Doctor (PhD) in the "Law and Society" program by the UDIMA. His line of research is teacher training in digital. It has different articles in impact journals, both JCR and SJR. He is currently a professor at the University of Almeria. He currently teaches undergraduate and courses in Methods of Research, Diagnosis, and Assessment in Education. His research interests are e-learning, online learning, and Moodle.

Javier Bravo-Agapito is Associate Professor and Senior Researcher at the Madrid Open Univerisity (MOU), Spain. He holds a Ph.D. in Computer Science and Telecommunications from the Universidad Autónoma de Madrid (2010). He has collaborated with researchers from recognized institutions in France and the United States. He collaborated with Prof. Serge Garlatti at Télécom Bretagne, Brest, France, and with Prof. Peter Brusilovsky at the University of Pittsburgh, Pennsylvania. Currently, his research interests focus on e-learning, adaptive educational hypermedia systems, and data mining. 


\section{References}

Abdelmalak, M. M. M. (2015). Web 2.0 technologies and building online learning communities: Students' perspectives. Online Learning, 19(2), 1-20. doi:http://dx.doi.org/10.24059/olj.v19i2.413

Adekunle, P.A., Omoba, R.O., \& Tella, A. (2007). Attitudes of librarians in selected Nigerian universities towards the use of ICT. Library Philosophy and Practice, 9(2), 1-8.

Aesaert, K., Van Nijlen, D., Vanderlinde, R., \& van Braak, J. (2014). Direct measures of digital information processing and communication skills in primary education: using item response theory for the development and validation of an ICT competence scale. Computers \& Education, 76, 168-181. doi:https://doi.org/10.1016/j.compedu.2014.03.013

Aesaert, K., Voogt, J., Kuiper, E., \& van Braak, J. (2017). Accuracy and bias of ICT selfefficacy: An empirical study into students' over-and underestimation of their ICT competences. Computers in Human Behavior, 75, 92-102. doi:https://doi.org/10.1016/j.chb.2017.05.010

Ahmed, S. S. (2017). User's attitude towards ICT in Dhaka. ANGLISTICUM: Journal of the Association for Anglo-American Studies, 6(8), 31-54. doi:http://dx.doi.org/10.0001/(aj).v6i8.1504.g2012

Alhom, M. \& Courtney, M. (2018). Educational data mining: A case study perspectives from primary to university education in Australia. Information Technology and Computer Science, 2, 1-9. doi:10.5815/ijitcs.2018.02.01

Ayub, H. (2017). Parental influence and attitude of students towards technical education and vocational training. International Journal of Information and Education Technology, 7(7), 534-538. doi:10.18178/ijiet.2017.7.7.925

Binder, M., \& Niederle, U. M. (2006). Institutions as determinants of preference change: One way relation? Papers on economics and evolution, 0607, 1-24. http://hdl.handle.net/10419/31863

Brown, T. A., \& Moore, M. T. (2014). Confirmatory Factor Analysis. In R. H. Hoyle (Ed.), Handbook of structural equation modeling (pp. 361-379). Guilford.

Carrera, X., Vaquero Tió, E., \& Balsells, M. (2011). Instrumento de evaluación de competencias digitales para adolescentes en riesgo social [Instrument for the evaluation of digital competency for adolescents in social risk]. Edutec: Revista Electrónica de Tecnología Educativa, 35, 1-25. doi:https://doi.org/10.21556/edutec.2011.35.410

Casillas, S., Cabezas, M., Ibarra, M. S., \& Rodríguez, G. (2017). Evaluation of digital competence from a gender perspective. Proceedings of the 5th International Conference on Technological Ecosystems for Enhancing Multiculturality, 1-5. doi:https://doi.org/10.1145/3144826.3145372 
Cervera, M. G., Vidal, C. E., \& Martínez, J. G. (2011). INCOTIC. Una herramienta para la autoevaluación diagnóstica de la competencia digital en la universidad [INCOTIC. A tool for the diagnostic self-evaluation of the digital competency in the university]. Profesorado: Revista de Currículum y Formación de Profesorado, 15(1), 75-90.

Edmunds, R., Thorpe, M., \& Conole, G. (2012). Student attitudes towards and use of ICT in course study, work and social activity: A technology acceptance model approach. British Journal of Educational Technology, 43(1), 71-84. doi:https://doi.org/10.1111/j.14678535.2010.01142.x

Fancovicová, J., \& Prokop, P. (2008). Students' attitude toward computer use in Slovakia. Eurasia Journal of Mathematics, Science and Technology Education, 4(3), 255-262. doi:https://doi.org/10.12973/ejmste/75347

Gallardo, E., Marqués, L., \& Bullen, M. (2015). El estudiante en la educación superior: Usos académicos y sociales de la tecnología digital [The student in higher education: Academic and social uses of the digital technology]. Universities and Knowledge Society Journal, 12(1), 26-36. doi:http://dx.doi.org/10.7238/rusc.v12i1.2078

Gallego, M.J., Gámiz, V. \& Gutiérrez, E. (2010). El futuro docente ante las competencias en el uso de las tecnologías de la información y comunicación para enseñar [The future teacher facing the competences in the use of information and communication technologies to teach]. EDUTEC. Revista electrónica de tecnología educativa, 34, 1-18.

Garcia, I., Escofet, A., \& Gros, B. (2013). Students' attitude towards ICT learning uses: A comparison between digital learners in blended and virtual universities. European Journal of Open, Distance and E-learning, 16(2), 1-10.

Hair, J., Black, W., Babin, B., \& Anderson, R. (2010). Multivariate data analysis (7th ed.). Prentice Hall, Inc.

He, T., \& Zhu, C. (2017). Digital informal learning among Chinese university students: The effects of digital competence and personal factors. International Journal of Educational Technology in Higher Education, 14(1), 1-19. doi:https://doi.org/10.1186/s41239-0170082-x

Jöreskog, K., \& Sörbom, D. (2006). Lisrel 8.80: A guide to the program and applications. SPSS Inc.

Kar, D., Saha, B., \& Mondal, B. C. (2014). Attitude of university students towards e-learning in West Bengal. American Journal of Educational Research, 2(8), 669-673.

doi:10.12691/education-2-8-16

Kerimbayev, N., Kultan, J., Abdykarimova, S., \& Akramova, A. (2017). LMS Moodle: Distance international education in cooperation of higher education institutions of different countries. Education and information technologies, 22(5), 2125-2139. doi:https://doi.org/10.1007/s10639-016-9534-5

Kubiatko, M. (2010). Czech university students' attitudes towards ICT used in science education. Journal of Technology and Information Education, 2(3), 20-25. doi:10.5507/jtie.2010.042 
Laabidi, H. (2017). Exploring the impact of the factor of gender on ICT integration in teaching. International Journal of English Language Teaching and Linguistics (IJELTAL), 1(2), 105-120.

Liaw, S. S., Huang, H. M., \& Chen, G. D. (2007). Surveying instructor and learner attitudes toward e-learning. Computers \& Education, 49(4), 1066-1080. doi:http://doi.org/10.1016/j.compedu.2006.01.001

Logan, J. W., Lundberg, O. H., Roth, L., \& Walsh, K. R. (2017). The effect of individual motivation and cognitive ability on student performance outcomes in a distance education environment. Journal of Learning in Higher Education, 13(1), 83-91.

Mantoro, T., Fitri, E. M., \& Usino, W. (2017). The impact of information and communication technology (ICT) toward learning process and students' attitudes. Advanced Science Letters, 23(2), 844-847. doi:https://doi.org/10.1166/as1.2017.7554

Meerza, A. H., \& Beauchamp, G. (2017). Factors influencing attitudes towards information and communication technology (ICT) amongst undergraduates: An empirical study conducted in Kuwait higher education institutions (KHEIs). TOJET: The Turkish Online Journal of Educational Technology, 16(2), 35-42. doi:http://hdl.handle.net/10369/8472

Mehra,V., \& Omidian, F. (2011). Examining students' attitudes towards e-learning: A case from India. Malaysian Journal of Educational Technology, 11(2), 13-18.

Mirete, A. B., García, F. A., \& Hernandez, F. (2015). Cuestionario para el estudio de la actitud, el conocimiento y el uso de TIC (ACUTIC) en Educación Superior [Questionnaire for the study of the attitude, knowledge and use of the ICT (ACUTIC) in higher education]. Revista Interuniversitaria de Formación del Profesorado, 29(2), 75-89.

Nisar ul Haq, M., \& Haque, M. (2018). Investigating the knowledge sharing among students in Pakistan. European Online Journal of Natural and Social Sciences: Proceedings, 7(1), 32-39.

Nketiah-Amponsah, E., Asamoah, M. K., Allassani, W., \& Aziale, L. K. (2017). Examining students' experience with the use of some selected ICT devices and applications for learning and their effect on academic performance. Journal of Computers in Education, 4(4), 441-460. doi:https://doi.org/10.1007/s40692-017-0089-2

Petko, D., Cantieni, A., \& Prasse, D. (2017). Perceived quality of educational technology matters: A secondary analysis of students' ICT use, ICT-related attitudes, and PISA 2012 test scores. Journal of Educational Computing Research, 54(8), 1070-1091. doi:https://doi.org/10.1177/0735633116649373

Podrug, N., Filipović, D., \& Kovač, M. (2017). Knowledge sharing and firm innovation capability in Croatian ICT companies. International Journal of Manpower, 38(4), 632644. doi:https://doi.org/10.1108/IJM-04-2016-0077

Rhema, A., \& Miliszewska, I. (2014). Analysis of student attitudes towards e-learning: The case of engineering students in Libya. Issues in Informing Science and Information Technology, 11, 169-190. doi:https://doi.org/10.28945/1987 
Rhode, J., Richter, S., Gowen, P., Miller, T., \& Wills, C. (2017). Understanding faculty use of the learning management system. Online Learning, 21(3), 68-86.

doi:http://dx.doi.org/10.24059/olj.v21i3.1217

Rodríguez, H., Restrepo, L. F. \& Aranzazu, D. (2014). Alfabetización informática y uso de sistemas de gestión del aprendizaje (LMS) en la docencia universitaria [Computer literacy and the use of Learning Management Systems (LMS) in university teaching]. Revista de la educación superior, 43(171), 139-159. doi:10.1016/j.resu.2015.03.004

Senkbeil, M., \& Ihme, J. M. (2017). Motivational factors predicting ICT literacy: First evidence on the structure of an ICT motivation inventory. Computers \& Education, 108, 145-158. doi:https://doi.org/10.1016/j.compedu.2017.02.003

Siragusa, L., \& Dixon, K. C. (2008). Planned behaviour: Student attitudes towards the use of ICT interactions in higher education. Proceedings Ascilite Melbourne, 942-953.

Stošić, L., \& Fadiya, S. O. (2017). The attitudes of students towards the use of ICT during their studies. Российский психологический журнал, 1(1), 135-148. doi:http://dx.doi.org/10.21702/rpj.2017.1.9

Tejedor, F. J., García-Varcarcel, A., \& Prada, S. (2009). Medida de actitudes del profesorado universitario hacia la integración de las TIC [Measure of attitudes of the university teachers towards the ICT integration]. Comunicar, 33(17), 115-124. doi:10.3916/c332009-03-002

Viberg, O., \& Grönlund, Å. (2017). Understanding students' learning practices: challenges for design and integration of mobile technology into distance education. Learning, Media and Technology, 42(3), 357-377. doi:https://doi.org/10.1080/17439884.2016.1088869

World Medical Association. (2001). Declaration of Helsinki. WMA

Yang, S., \& Kwok, D. (2017). A study of students' attitudes towards using ICT in a social constructivist environment. Australasian Journal of Educational Technology, 33(5), 5062. doi:https://doi.org/10.14742/ajet.2890 